\title{
Международное право и национальное право: пути взаимодействия Рецензия на монографию: Гаврилов В.В. Понятие и взаимодействие международной и национальной правовых систем: Монография. Владивосток: Изд-во Дальневосточного ун-та, 2005. 216 с.
}

Фархутоинов И.З.*

Представленная к рецензированию монография написана на актуальнейшую с точки зрения теории и практики современного международного права тему. Проблемы соотношения и взаимодействия международного и внутригосударственного права приобрели сегодня особо принципиальное значение в силу бурно поступательных глобализационных процессов во всех сферах человеческой жизнедеятельности. А это ставит новые вопросы об основных парадигмах мировых интеграционных процессов и их правовом измерении, и в особенности по поводу динамики соотношения этих двух самостоятельных правовых систем. Между тем в отечественной юридической науке не уделяется достаточного внимания этим животрепещущим проблемам и тенденциям далынйшего развития международного права. В.В. Гаврилову, кстати, 12 мая 2006 г. успешно защитившему диссертацию на соискание ученой степени доктора юридических наук по специальности 12.00.10 «Международное право. Европейское право» в Диссертационном совете Казанского государственного университета, в значительной мере удалось восполнить этот пробел.

Основная заявочная цель книги состоит в том, чтобы в максимально доступной форме способствовать раскрьптию понятия и взаимодействия международной и национальной правовых систем. Книга В.В. Гаврилова - это очередной важный труд подающего большие надежды молодого ученого. В монографии рассматриваются вопросы развития концепции правовой системы в общей теории права и международно-правовой доктрине во второй половине XX - начале XXI века, дается определения и анализируется содержание категорий «нацио-

* Фархутдинов Инсур Забирович - д.ю.н., с.н.с. Центра международно-правовых исследований ИГ иП РАН. 
нальная правовая система» и «международная правовая система», раскрываются и основные направления их взаимодействия. Значительное место уделено анализу теоретических концепций и характеристике юридического механизма действия международных правовьх норм в правовых системах современных государств.

Гаврилов Вячеслав Вячеславович, доктор юридических наук, профессор, родился в г. Находка Приморского края. В 1985 г. с отличием окончил юридический факультет ДВГУ, в 1994 г. - аспирантуру Казанского государственного университета. Там же защитил диссертацию на соискание ученой степени кандидата юридических наук. С 1995 г. по сегодняाшний день успешпо трудится заведуюшим кафедрой международного права и деканом международно-правового факультета Юридического института Дальневосточного государственного университета.

В.В. Гаврилов является одним из разработчиков Устава Приморского края. Автор более 50 учебно-методических и научных публикаций по актуальным проблемам межлународного публичного и международного частного права. Принимал участие в работе научньх, научно-практических и учебных семинаров, симпозиумов и конференций в США, Венгрии и Франции. В 2003 г. был награжден почетной грамотой губернатора Приморского края за активное участие в законотворческой и правоприменительной деятельности органов государственной власти края. Проводит значительную работу по пропаганде межлународно-правовых знаний в качестве члена исполкома Российской ассоциации международного права на дальних рубежах нашего отечества.

Приятно отметить также то обстоятельство, что рецензируемую книгу автор посвятил памяти своего учителя Давида Исааковича Фельдмана, который, будучи основоположником казанской школы международного права, оставил большой след в теории и практике отечественной юридической науки. Профессор Д.И. Фельдман, корифей советской научнойшколы международного права, вырастил целую плеяду блестящих ученых - юристов-международников, в частности таких известных сегодня профессоров, как Г.И. Курдюков, Р.М. Валеев идр. Эту эстафету достойно принял сегодня молодой доктор В.В. Гаврилов, что подтверждает весьма благосклонная реакция известных ученых на рецензируемую книгу. В связи с этим особо отметим мнение на сей счет уже современного патриарха российской науки международного права профессора, руководителя Центра международно-пра- 
вовых исследований Института государства и права РАН Игоря Ивановича Лукашука, который назвал монографию В.В. Гаврилова новым научным прорывом в российской науке международного права.

Полноценный и всесторонний анализ проблемы соотношения и взаимодействия международной и национальных правовых систем невозможен, как считает Вячеслав Вячеславович, без четкого определения предметной базы исследования и соответствующего понятийного аппарата. Это тем более необходимо потому, что в юридической литературе понятие и содержание ключевой в этом смысле категории «правовая система» различными исследователями определяется по-разному. Указанное обстоятельство может быть объяснено, по мнению автора, не только различием индивидуальных подходов отдельных авторов к данной проблеме, но и их принадлежностью к различным ответвлениям юридической науки, и прежде всего к сферам науки международного права и общей теории права.

Для В.В. Гаврилова характерно бережное отношение к истории нашей юридической науки. Утверждение некоторыми авторами об отсутствии в советской международно-правовой литературе внимания к проблеме взаимодействия международного права и внутригосударственного права представляется для него не совсем справедливым. Может быть, это внимание было недостаточно ярко выраженным и последовательным. Однако, продолжает он, несомненным представляется тот факт, что в отечественной доктрине международного права периода 70-80-х годов прошлого века существовал целый ряд исследований, в рамках которых предпринимались попьпки определить основные параметры универсальной социальной системы, включающей не только международное право как специфическую совокупность юридических норм, но и его субъекты, возникающие между ними правоотношения, формы и способы осуществления международно-правовых норм и даже международное правосознание. Для подтверждения своей мысли молодой ученый обрашается, например, к творческому наследию профессора Н.А. Ушакова, который, считал, что «международная правовая система состоит из следующих элементов: международное право, международная юридическая практика, межлународно-правовая идеология, находящая свое выражение в международном правосознании».

В.В. Гаврилов на основе внимательного исследования достижений современной российской международно-правовой доктрины заключа- 
ет, что она постепенно отходит от узкого понимания международной правовой системы как системы исключительно межгосударственных отношений, регулируемых на правовом уровне нормами международного публичного права. В ее рамках происходит, как верно отмечает он, осознание того факта, что исключение из числа субъектов международной правовой системы негосударственных акторов, и, прежде всего физических и юридических лиц, равно как и отрицание возможного международно-правового регулирования отношений с их участием, не соответствует ни современной практике развития международных отношений, ни существующим механизмам и способам их нормативно-правовой регламентации.

В соответствии с современной трактовкой предмета международно-правового регулирования более близким к действительности представляется для профессора В.В. Гаврилова определение субъекта международного права как участника международных отноиений, обладающего правами и обязанностями, непосредственно представляемыми или возлагаемыми на него международно-правовыми нормами. При этом традиционное подразделение субъектов на первичные и производные автор рецензируемой книги рекомендует дополнить разграничением на субъекты, наделенные нормотворческой функцией, и субъекты, ею не обладающие. Свой ход мысли он подтверждает тем, что подобное положение существует и во внутригосударственном праве.

К последней разновидности субъектов международного права Вячеслав Вячеславович относит физические лица, а также международные неправительственные организации, международные хозяйственные объединения и юридические лица отдельных государств (включая транснационалыные корпорации), которым международно-правовыми нормами предоставлены определенные права или на которые возложены обязанности, имеюшие юридически значимое содержание. При этом, признавая за физическими лицами статус субъектов международного права, ученый специально подчеркивает, что индивиды обладают им лишь постольку и в тех пределах, поскольку это санкционировано и определено нормами межгосударственных соглашений, непосредственно предоставляющих физическим лицам такие права или возлагающих на них обязанности.

При такой постановке вопроса высказываемые в научной литературе опасения об изменении природы международного права, которое 
неизбежно должно последовать вслед за приобретением международной правосубъектности индивидами, по мнению ученого, лишаются всякого основания. Речь в данном случае идет не об изменении межгосударственного характера межлународного права, а о появлении в его рамках новой разновидности субъектов, которые выступают в качестве «адресатов» международно-правовых норм, не обладая при этом нормотворческими функциями.

Стремительное вторжение регулирующего воздействия международного права в сферу внутренней компетенции государств, расширение его субъектной основы лишний раз доказывает, по мнению В.В. Гаврилова, тот очевидный факт, что, хотя межлународное и внутригосударственное право представляют собой различные типы юридических регуляторов общественных отношений, они существуют в рамках единой родовой правовой общности.

Автор умело, шаг за шагом доказывает, что международные правовые предписания, как и нормы внутригосударственного права в своей сфере, не только выступают в качестве нормативной основы международной правовой системы, но и играют важную роль в ее функционировании, определяя компетенцию и порядок деятельности различных межгосударственных объединений, а также процедуру создания и осуществления в рамках мирового сообшества соответствующих источников права. Они также оказывают, подкрепляет автор далее свою идею, существенное влияние на определение содержания механизма имплементации норм международного права на внутригосударственном уровне. Он отмечает, что сегодня государства свободны в выборе путей и средств реализации международных правовых предписаний на своей территории настолько, насколько эти вопросы не урегулированы международным правом.

В связи с этим автор монографии обращается к концепции И.И. Лукашука, который также считает, что принцип свободы выбора государством средств реализации норм международного права в целом сохраняет свос основополагающее значение, а ограничение его действия предписаниями соответствуюших международно-правовых норм он рассматривает скорее как исклочение. В своей практике государства исходят из того, что осуществление международно-правовьх норм во внутригосударственной сфере должно происходить на основе национального права. Другими словами, определение механизма обеспечения выполнения обязательств по международному праву, заключа- 
ст автор вслед за И.И. Лукашуком, должно быть оставлено на усмотрение самого государства.

В.В. Гаврилов выделяет две основные формы помощи, которуг внутригосударственное право оказывает межлународному праву в процессе применения его норм. В первом случае речь идет о ситуации, когда основная цель договорных или обычных норм международного права заключастся в урегулировании отношений, выходящих за рамки государственных границ (например, при регламентации вопросов политического, военного, научно-технического или культурного сотрудничества государств). Так как нормы международного права всегда обязывают государство в целом, а не его органы, то основная задача национального права будет состоять здесь в определении подразделений и структур, ответственных за обеспечение реализации их положений на практике. Другими словами, развивая далее эту идею, Вячеслав Вячеславович подчеркивает, что внутригосударственное право в данном случае только обеспечивает нормативную основу функционирования и взаимодействия государственных органов и должностных лиц в процессе выполнения ими положений конкретного международного правового акта или других источников международных правовых обязательств.

Общепринято считать, что регулирующее воздействие международных правовых норм в подобных ситуациях, как правило, не затрагивает отношений с участием субъектов национального права отдельных стран. Поэтому, как считает автор рецензируемой монографии, в подавляющем болышинстве случаев, оно непорождает конкуренщии между источниками международного и внутригосударственного права и не требует каких-либо дополнительных нормотворческих усилий со стороны компетентных органов соответствующего государства.

Совершенно другую ситуацию В.В. Гаврилов видит тогда, когда конечной целью действия того или иного международного правового акта являстся достижение определенной степени урегулированности отношений между субъьктами национального права одного или нескольких государств. Речь идет о вопросах защиты прав человека, порядке заключения и исполнения внешнеэкономических сделок, об охране авторских прав.

Особые правоотношения складываются также при правовом регулировании иностранньх инвестиций. Российская Федерация, например, заключила более 50 двусторонних соглашений о взаимном поощрении 
и защите капиталовложений. Эти международные межправительственные договоры непосредственно регулируют частноправовые отношения с участием иностранного инвестора, скажем, в сфере урегулирования споров межлу хозяйствующими субъектами из различных стран. Здесь, как и в вышеотмеченных случаях, международное право фактически «вторгается», как пишет Вячеслав Вячеславович, в традиционную сферу действия права национального, и взаимодействие этих нормативных образований уже не будет носить только функциональный характер. В данном случае задача внутригосударственного права заключается в том, чтобы определить возможность и условия, а также при помощи других элементов национальной правовой системы обеспечить должный порядок осуществления международных правовых норм внутри страны.

Объективная взаимная обусловленность международной и национальной правовых систем дает основание автору рассматривать их в качестве «сложного системного комплекса, обшность и одновременно расчлененность которого берет истоки в суверенитете и находит свое проявление в генезисе становления и развития каждой из систем, а также в их структуре, механизме и тенденциях функционирования». Признание общности и параллельности развития указанных системных конструкций, в свою очередь, порождает потребность в изучении основньх направлений и форм их взаимодействия.

Процесс взаимодействия происходит в рамках юридической практики и охватывает все уровни международной и национальных правовьх систем - нормативньй, институциональньй и идеологический. При этом В.В. Гаврилов выделяет два основных направления взаимодействия нормативных составляющих международной и национальных правовых систем. Первое из них он обозначает в отношении формирования юридических правил поведения и поэтому условно называет «содержательным». Второе автор выделяет в процессе осуществления предписаний правовых норм на практике и, исходя из этого, обозначает как «регулятивное». В рамках каждого из этих направлений могут быть также выделены, считает он, специальные формы и способы рассматриваемого взаимодействия.

Говоря о содержательном взаимодействии нормативных компонентов международной и национальных правовых систем, Вячеслав Вячеславович подчеркивает, что оно является одним из важнейших факторов, обеспечивающих их социально-нормативную согласован- 
ность. Следуя концепции известного профессора Г.В. Игнатенко из Уральской государственной юридической академии г. Екатеринбурга, автор рецензируемой монографии повторяет, что в процессе правового регулирования общественных отношений государство выражает свои интересы, объективирует свою волю в одних случаях в форме собственного государственного акта (закона и т.д.), в других - в форме согласованного межгосударственного акта (договора и т.д.). Стало быть, международные договоры и закрепленные в них нормы для государств-участников представляюо собой не «инородную» правовую материю, не «постороннее) право, а такой продукт нормотворчества, в котором в той или иной степени (в зависимости от многих обстоятельств) воплощены государственные потребности.

Можно высказать и некоторые замечания и пожелания в отношении рецензируемой книги. Например, на с. 158 автор утверждает, что в действительности на практике существует только два самостоятельных способа согласования международных и национальньх правовых норм - отсылка и инкорпорация. Данная мысль В.В. Гаврилова, думается, не подтверждена в должной мере его собственными рассуждениями. Тем более что многие специалисты отдают предпочтение такому методу реализации международно-правовых норм, как имплементация. Кроме того, в монографии недостает обращения к отечественной правоприменительной практике в исследуемой сфере. Однако эти замечания носят дискуссионный характер, и лишний раз подтверждают чрезмерную сложность темы научного исследования В.В. Гаврилова.

Таким образом, обьективный анализ рецензируемого комплексного исследования свидетельствует о его научно-практической полезности. Книга предназначена для преподавателей и студентов юридических вузов, работников государственньх органов и правоприменительных структур, а также для всех интересующихся вопросами теории международного права и практики его реализации. С уверенностью можно сказать, что рецензируемая монография стала важным вкладом в дальнейшее развитие российской науки и практики международного права. 


\section{Review of the monograph by Gavrilov V. "The concept and interaction of international and national legal systems". Vladivostok. 2005.216 pages. (Summary)}

Farhutdinov I.Z.*

The problems of development conception legal system in the contemporary common lay theory and international legal doctrine, maintenance of categories «international legal system» and «national legal system», precondition and general directions of their interaction are considered in this monograph. The analysis of theoretical conceptions and description of juridical mechanism action of international legal norms in law systems of contemporary states are discussed too.

In the opinion of author international law and national law are absolutely different legal orders. That is why former can not direct regulator of relations in the sphere of latter.

For conferring force to the international legal norms inside state they must transform in the norms of national law, in other words, acquire the force of norms internal state law.

The procedure of transformation is characterized for all cases and methods of putting in action of international legal norms inside state and realization of transformation needs an issuance respective national legal act.

The international legal norms occupy a solitary post in the normative massif of the Russian legislative system, functions equally with the Russian law, must interpret and use in the light purposes and principles of international law, and intergovernmental treaty.

* Farhutdinov Insur Zabirovich - Doctor of Laws, senior researcher at the Center of International Law Studies of the Institute of State and Law, Russian Academy of Sciences. 